\section{B A Institute of \\ YK Business Administration \\ 六下 \\ Karachi \\ Leadership and Ideas for Tomorrow}

Business Review

Volume 14 Issue 2 July-December 2019

7-1-2019

\title{
Board structure and dividend smoothing: A case of Pakistani listed firms
}

Zahid Ali

School of Accounting, Zhongnan University of Economics and Law

Assad Ullah

School of Management, Huazhong University of Science and Technology

Arshad Ali

Department of Commerce and Management Sciences, University of Malakand

Follow this and additional works at: https://ir.iba.edu.pk/businessreview

Part of the Finance Commons

c) (i)

This work is licensed under a Creative Commons Attribution 4.0 International License.

\section{Recommended Citation}

Ali, Z., Ullah, A., \& Ali, A. (2019). Board structure and dividend smoothing: A case of Pakistani listed firms. Business Review, 14(2), 65-91. Retrieved from https://doi.org/10.54784/1990-6587.1018

This article is brought to you by iRepository for open access under the Creative Commons Attribution 4.0 License and is available at https://ir.iba.edu.pk/businessreview/vol14/iss2/5. For more information, please contact irepository@iba.edu.pk. 


\title{
Board structure and dividend smoothing: A case of Pakistani listed firms
}

\author{
Zahid Ali · Assad Ullah • Arshad Ali
}

\begin{abstract}
The purpose of this study is to empirically examine the effects of ownership and board structure on dividend smoothing for listed non-financial firms for the period 2005-2015 on the Pakistan Stock Exchange (PSX) in the light of agency and information asymmetry theory. Two measures, speed of adjustment and relative volatility are used to estimate dividend smoothing. Tobit regression is used for analyzing the effects of board structure on dividend smoothing measured via speed of adjustment while OLS is used for relative volatility. Additionally, the study applies the technique of principal component analysis (PCA) for board index. The results reveal that firms with large boards have a high level of dividend smoothing in Pakistan. They less frequently increase, cut, initiate and omit dividends. The substitution role of board independence is depicted by the negative association of board independence with dividend smoothing. Furthermore, independent audit committees and dividend smoothing are also found to be negatively associated.
\end{abstract}

Keywords Dividend smoothing · Corporate governance · Substitution • Pakistan.

\section{Introduction}

Many scholars have found empirical evidence of an increase in prices in response to dividend initiation and negative reaction to dividend omission and cuts (Lintner 1956). This situation is so serious that managers go for external financing and forgo economically attractive projects to avoid dividend cuts (Brav et al 2005; Gordon 1963). The market puts a premium on companies with relatively

Zahid Ali

School of Accounting, Zhongnan University of Economics and Law

Assad Ullah

School of Management, Huazhong University of Science and Technology

Arshad Ali

Department of Commerce and Management Sciences, University of Malakand

E-mail: arshad.ali@uom.edu.pk 


\section{Z. Ali et al}

stable or consistently increasing dividends. Therefore, corporate management exerts efforts to achieve smoothness of dividends (Lintner 1956). Lintner's findings were confirmed by many authors (Fudenberg and Tirole 1995; Lambrecht and Myers 2010; Allen et al 2000; Leary and Michaely 2011; Jeong 2011, 2013). Despite many empirical studies in the extant literature regarding confirmation of dividend smoothing, scarce literature exists on "Why corporations smooth dividends and whether dividend smoothing is linked to board structure?".

Supporters of Easterbrook (1984) and Jensen (1986), provide empirical evidence that smoothed dividends are the source of alleviating manager-shareholder conflict. This application of smooth dividend policy by corporations exposes them to the financial markets for external financing (Allen et al 2000; Fudenberg and Tirole 1995). In contrast to this, corporations may use dividends as signals to convey information about their current and future earnings (Kumar 1988; Brennan and Thakor 1990; Chemmanur et al 2010; Guttman et al 2010; Leary and Michaely 2011). Dividends are used as signals when information asymmetry exists between managers and outside shareholders or between informed and un-informed investors. Therefore, young opaque firms with few growth opportunities and less tangible assets are more likely to smooth dividends (Brennan and Thakor 1990; Leary and Michaely 2011).

The purpose of this study is to empirically examine the impact of board structure on dividend smoothing for listed non-financial firms on the Pakistan Stock Exchange (PSX). The study aims at providing a comprehensive analysis of the major aspects of dividend smoothing in the light of agency and signaling theories of dividends. The environment of Pakistan characterized by family concentrated ownership, weak corporate governance with low compliance and weak shareholders' rights provides the opportunity to investigate substitution or outcome role of dividend smoothing to corporate governance.

This study contributes to the limited literature on dividend smoothing. Few studies have addressed the cross sectional differences in dividend smoothing behavior among firms by giving attention to the firm level financial factors and some country-level macro variables. This study attempts to fill this void in current literature. Till now no research has addressed the impact of board structure on dividend smoothing in the asymmetric context. This study addresses the impact of board structure on dividend smoothing via separating dividend changing events of increases, decreases, initiations and omissions. Therefore, it contributes to literature on corporate governance and dividend smoothing. Regulators in Pakistan, mostly focus on corporate governance regulations and its compliance for protecting minority shareholders. However, the substitution evidence of dividend smoothing and corporate governance provides a new insight to regulators for protecting minority shareholders with the help of dividend smoothing. 


\section{Literature review and hypotheses development}

\subsection{Board structure and dividend smoothing}

As organizations grow, shareholders and management's interests may not converge. It is expected that management then pursues their personal benefits rather than shareholders (Jensen and Meckling 1976). Under this scenario corporate governance structures are developed by shareholders to gain effective control over some of the decisions of the management (Fama and Jensen 1983). The authors depict that these governance structures are designed according to the needs and complications of the firms.

Regular and stable payout policies have two-way effects on companies. Smooth dividends declared by companies help them to reduce excess cash. This decreases the chances of expropriation by the management but, it may expose the company to the external financial market, which may not only act like a barometer but may also increase the financial cost of the company. Therefore, companies always try to achieve the optimal dividend policy and appropriate level of dividend smoothing.

Dahya et al (1996) define corporate governance as the pattern in which companies are governed and controlled and the pattern in which those who are responsible, are made accountable to the shareholders of the companies. Corporate governance literature is regularly addressed by the researchers, and some of them believe that competition among companies and globalization converts corporate governance as a standard rule across the globe. Independent boards, external candidature for CEOs, increasing trend of CEO's compensation for their shorter tenures and lower prerequisite consumptions, are now global corporate governance trends (Hermalin 2005).

Similar results were produced by Khanna et al (2006) in their cross-country analysis. According to them, independent countries have similar corporate governance rules. They further depicted that globalization may force these countries to formulate similar corporate governance standards. Similarly, Gillan (2006) developed a model that incorporated the board of directors and management for internal governance and laws and capital markets of the countries for external mechanism. In contrast, many studies depict that there may be little agreement on the best board structure across the globe, the majority of constitutes develop best corporate governance rules according to their own complexities and requirements i.e. divergence of corporate governance (Gillan and Starks 2003).

Corporate governance aims to achieve a balance among different stakeholder's goals and involves efficient and effective use of resources to become answerable to the stakeholders (Sharif and Rashid 2014). Famous international scandals like Parmalat, WorldCom, Enron, Ahold and local corporate governance scandals in Pakistan like Taj company, Crescent Bank Fraud, PTCL privatization, ENGRO Group of Companies and Mehran Bank have raised ethical issues regarding boards of directors, auditors, risks and controlling of risks and compensation of directors. Corporate governance has therefore become a focal point after these scandals and it requires the efficient and effective use of resources that are beneficial to all stakeholders of the company(Sharif and

Business Review: (2019) 14(2):65-91 


\section{Z. Ali et al}

Rashid 2014).

The relationship between dividends and corporate governance is quite hazy in literature. On one hand, companies with weak corporate governance follow a high dividend policy that substitutes for corporate governance. In such companies, management uses dividends to establish trust for future equity raising (Hu and Kumar 2004). On the other hand, according to the outcome hypothesis companies with strong corporate governance where investor rights are strongly protected are empowered to demand higher dividends (Sawicki 2009). Jiraporn et al (2011) also, found that companies with strong corporate governance offer higher dividends.

The literature on corporate governance depicts its linkage with company value, financial performance, takeovers, and reliability of financial information, CEO compensation, capital structure, dividends and dividend smoothing. Gompers et al (2003) constructed a corporate governance index using 24 corporate governance provisions by taking 1500 US companies and found that company value and corporate governance are associated with each other. Bebchuk et al (2008) studied 1800 companies for the period of 1990-2003. They incorporated six corporate governance provisions and found that high entrenchment index is associated with the negative performance of companies. Brown and Caylor (2006) considered 51 corporate governance firm-specific provisions by using 1,868 U.S. firms and found a positive association between corporate governance and firm value. But contrary to these studies Cheung et al (2008) developed a corporate governance index for Chinese companies and found no association between corporate governance and firm value.

More recently Javakhadze et al (2014) by investigating non-financial companies from 24 countries over the period of 1999 to 2011, found that dividend smoothing and corporate governance follow the substitution hypothesis. They found that companies with strong corporate governance exhibit less dividend smoothing. Similarly Leary and Michaely (2011), concluded that companies with the weak corporate governance exhibit more dividend smoothing. The authors found that firms with weak growth potentials and corporate governance, having greater proportions holding by institutions go for higher dividend smoothing.

Keeping in view the above gap in literature, the current study addresses board characteristics i.e. board size, board independence, audit committee independence and $\mathrm{CEO} /$ chairperson duality, and investigates its impact on dividend smoothing.

\subsection{Board size and dividend smoothing}

Fama and Jensen (1983) argued that the board of directors of a firm contributes significantly to reduce the agency problem as the central focus of corporate governance is to monitor companies' executive management. However, boards can effectively monitor management and can take corrective actions only if they have enough representation of independent directors (Jensen 1986; Setia-Atmaja 2009).

Most of the previous literature on corporate governance has addressed the 
board of directors' size, its independence, its composition and board activities. While concentrating on a sample of 7000 U.S firms over a period of 1990 to 2004 Linck et al (2008) found the size of the board, the proportion of independent directors and board leadership to be significant determinants of the board of directors' structure. They further argued that during 1990s large firms have reduced their board size while small firms have maintained its boards flat. Among other studies on corporate board of directors (Boone et al 2007) related the board size to company's life cycle and CEO's links with outside directors. They found that companies increase their board size and appoint more outside directors as they move towards maturity. Further, they also found that board composition is the outcome of the CEO's negotiation with outside directors. Similarly, Vafeas (2000) found the inverse relationship of board meetings frequency and firm's value by addressing 307 U.S. firms for the period 1990-1994. Yermack (1996) concentrated on 452 large U.S firms for the period 1984-1991 and found that small boards are more effective than larger ones.

Hermalin and Weisbach (1991) related board structure and board incentives with firm performance for 142 NYSE firms during 1971-1983 but failed to find a significant relationship between the proportion of outside directors and firm performance. On the other hand, Krivogorsky (2006) related board structure and firm performance for 87 European firms and found that the higher the proportion of independent directors, the higher is the firm's performance.

In accordance with the agency cost theory, the size of the firm's board of directors can influence dividend smoothing in two ways. Large boards have more diversity and more external linkages, therefore, they have the ability to monitor executive management effectively (Fiegener et al 2000). In contrast Ghosh and Sirmans (2006) argued that managers exploit this weak monitoring of large boards and boards populated by older directors and pay a lower level of dividends. Therefore, firms with larger boards face a lower level of agency problem according to the agency theory; and exhibit lower levels of dividend smoothing.

On the other side of the coin, Jensen (1993) and Yermack (1996) argued that it is not necessary, that larger boards may be more efficient monitors. They argued that large boards have the issue of coordination between board members. They stated that small boards with enough proportion of independent directors are more efficient and can monitor executive management effectively. Therefore, from this perspective firms with large boards suffer more from the agency problem and smooth their dividends more.

Most of the firms in Pakistan are controlled by families, therefore, they don't appoint directors who limit their business control. Therefore, in large it is expected that boards of directors in Pakistan have weak monitoring role and substitute this by large and smooth dividends which are in accordance with the substitution hypothesis (La Porta et al 2000). Based on the above, the following hypothesis is proposed:

H1: There is a positive relationship between the size of the board and dividend smoothing.

Business Review: (2019) 14(2):65-91 
Shareholders elect the board of directors for the management and control of the firm. Later on the board of directors recruits officers and delegates authority for routine decision making control to the management. However, they retain the authority of hiring and firing and compensating management including the CEO. Naturally, the management tries their best to attain majority of the positions on the board and elect the $\mathrm{CEO}$ as the chairman to safeguard their personal interests. Boards having duality and majorly made up of executive directors are usually not good monitors and are not be able to challenge management decisions (Jensen 1993).

Non-executive or outside director means, director of the company who is not assigned managerial or administrative responsibilities (SECP Corporate Governance rules, 2013). Corporate governance rules (2013) issued by SECP, had asked all companies operating in Pakistan to have $40 \%$ independent directors on their boards by 2015 and a majority of independent directors by 2017 . However, only electing independent/ non-executive directors on the board doesn't protect minority shareholders because not all outside directors challenge management rather they safeguard self-interest. Therefore, SECP has addressed characteristics of independent directors in its 2013 rules as some outside directors' monitor but others don't.

Independent boards improve the decision-making process and exhibit good monitoring and supervision. According to the agency theory, independent directors are good monitors and can safeguard shareholder's interest better (Jensen and Meckling 1976; Armstrong et al 2014; Sharma 2011). Independent directors can give independent judgement, free of management influence (Fama and Jensen 1983; Linck et al 2008). These boards can protect minority shareholders from expropriation by the major shareholders and hence reduce both type I and type II agency problem (Raheja 2005; Sharma 2011; Armstrong et al 2014). Stakeholder theory depicts that independent directors outperform insiders in guarding the interests of the stakeholders because they are more experienced and have more ethical and legal obligations (Rodriguez-Dominguez et al 2009). They are more conservative than executive directors and reduce agency cost mounting from information asymmetry between shareholders and management. However this is not always true, sometimes executive directors reveal partial information to boards and to outside directors in order to prevent full information access to shareholders (Yermack 1996; Armstrong et al 2014).

Previous literature depicts that the presence of more executive directors on the board affects disclosure (Cheng and Courtenay 2006) and performance (Cho and Kim 2007) negatively. Ruiz-Barbadillo et al (2009) found that the presence of a higher proportion of executive directors enhances management dominance over the board and ultimately these boards are less likely to support dividend payouts (Deshmukh et al 2013; Banerjee et al 2013). Raheja (2005) found that the optimal number of outside/non-executive directors are dependent on the private benefits of insiders, and found both to be positively linked. Companies having more executive directors on their boards are less likely to use dividend as a monitoring device for agency cost reduction because they can monitor man- 
agement by themselves effectively (Maury and Pajuste 2002; Krishna Prasanna 2014). Independent directors on the board ask for large dividends in order to counter the use of free cash flows for self-interest by management (Ghosh and Sirmans 2006). In contrast Cheung et al (2005) for Hong Kong and Su et al (2014) for China found a weak association of dividend payout with boards independence while How et al (2008) found that board independence lowers dividend payouts in Hong Kong. This study precedes with the notion that independent directors are effective monitors and can challenge management decisions. Therefore, we follow the substitution hypothesis that the requirement of smooth dividends will be reduced as long as a company elects more independent nonexecutive directors on its board. Based on the above the following hypothesis is proposed:

H2: There is negative relationship between board independence and dividend smoothing.

\subsection{Audit committee and dividend smoothing}

The audit committee is a standing committee of non-executive directors of the board (AICPA). It plays a vital role in corporate governance. According to the Corporate Governance Rules (2013) of the Public-Sector companies issued by the Securities and Exchange Commission of Pakistan, audit committee should be chaired by a non-executive director and neither chairman of the board nor CEO should be its member. The audit committee has the responsibility to monitor the internal audit department, review audit plans, annual and audit reports of the company. They have to look after the appointment of the external auditors, review accounting control and protect company's assets (Setia-Atmaja 2009). Another important responsibility of the audit committee is to make recommendations to the board of directors about the related party transactions during the period (SECP Corporate Governance Rules 2013).

The audit committee of the company is in the best position to identify any overruling by the management and react immediately (Lutz 2015). The Commission further states that company's internal audit is strengthened by its audit committee. The primary purpose of the audit committee is to safeguard the interests of the shareholders and this purpose can be achieved only if the committee is controlled by the external members.

McMullen (1996) have linked reliable information with the presence of the audit committee. But Beasley (1996) has presented quite opposite results i.e. the presence of audit committee is not likely to do anything with the reliability of the financial information. Merely the presence of the audit committee cannot stop management from overruling but the audit committee's independence is crucial to curtail the management and safeguard the interests of the shareholders. Audit committee's independence is positively linked with private benefits to the management (Setia-Atmaja 2009). That is the audit committee's role is increasing as chances of expropriation increase. Therefore, the presence of an independent audit committee is likely to reduce information asymmetry and the agency problem. Hence, the preference for a high level of smoothed dividends 


\section{Z. Ali et al}

will reduce. Keeping in view the above literature, the following hypothesis is proposed for the impact of the audit committee's independence on dividend smoothing.

H3: There is negative relationship between audit committee's independence and dividend smoothing.

\section{Methodology}

\subsection{Sample}

Sample of the study comprises of all listed non-financial firms on the Pakistan Stock Exchange (PSX) for the period 2005-15, however, data on certain variables like Earnings per share (EPS), Dividend per share (DPS) and the total dividend was included for the period ranging 1999-2015. Data is filtered according to table 1. EPS, DPS and data for control variables has been acquired from the balance sheet analysis of the State Bank of Pakistan (SBP). Stock prices information for return volatility has been collected from Khistocks.com and business recorder website. Data on firm's measure of risk (beta) has been collected from opendoors.pk while board structure related data were hand collected from the annual reports of the companies for period of 2005-2015.

Table 1: Sample selection

\begin{tabular}{clc}
\hline & Criteria & Firm-year obsv \\
\hline 1 & Initial data & 6962 \\
2 & After excluding firms never paid dividend during 1999-15 & 6056 \\
3 & After excluding firms never paid 3-years consecutive dividend & 4382 \\
4 & After excluding firms not having CG data & 2779 \\
5 & After excluding firms having less than 5-Years data & 2744 \\
6 & Finally 255 non-financial listed firms at KSE for 2005-15 & 2744 \\
\hline
\end{tabular}

Source: Author's calculation (2017)

\subsection{Variable measures}

Following Leary and Michaely (2011), this study uses two measures of dividend smoothing i.e. the speed of adjustment (SOA) and relative volatility (Rel Vol).

\subsubsection{Speed of adjustment (SOA)}

The study follows (Lintner 1956) for finding dividend smoothing measures of the listed Pakistani non-financial firms given by:

$$
\Delta D_{i t}=a_{i t}+c_{i 1}\left(r_{i} \text { Earnings }_{i t}+\text { Dividend }_{i, t-1}\right)+\epsilon_{i t}
$$

For measuring the level of dividend smoothing across firms, this study follows (Fama and Babiak (1968)) which is a modified form of (Lintner 1956) partial 
adjustment model by dividing earnings and dividends by the number of shares. Previous studies (Leary and Michaely 2011; Jeong 2011, 2013) have used this modified (Lintner 1956) model given by:

$$
\Delta D_{i t}=a_{i t}+c_{i 1}\left(r_{i} E P S_{i t}+D P S_{i, t-1}\right)+\epsilon_{i t}
$$

or

$$
\Delta D_{i t}=\beta_{0}+\beta_{1} E P S_{i t}+\beta_{2} D P S_{i, t-1}+\epsilon_{i t}
$$

Speed of adjustment (SOA) given by $c_{i}$, theoretically ranges between 0 and 1. As SOA approaches 1, the level of dividend smoothing lowers and as SOA approaches zero, it reflects a higher level of dividend smoothing. The level of dividend smoothing (SOA) is estimated as $\beta_{2}$ from this equation (Lintner 1956).

We follow a two step procedure to measure SOA, introduced by Leary and Michaely (2011) to improve the precision of the estimates. This two step procedure reduces small sample biases (Leary and Michaely 2011). Fist payout ratio is calculated by dividing common dividends by the net income. Then target payout ratio (TPR) is estimated as firm's median payout ratio for the entire sample period. By using the above target payout ratio we calculate the deviation from the target dividend for each firm-year observation through this equation.

$$
\Delta D_{i t}=\beta_{0}+\beta_{1} D e v_{i t}+\epsilon_{i t}
$$

where $D e v_{i t}=T P R_{i} \times E P S_{i t}-D P S_{i, t-1}$. Here speed of adjustment (SOA) represented by $\beta_{1}$ is estimated over the rolling window of six years for each firmyear observation. As an alternative measure of dividend smoothing to SOA, we use another proxy called relative volatility.

\subsubsection{Relative Volatility (Rel $\mathrm{Vol}$ )}

Leary and Michaely (2011) introduced another measure of dividend smoothingthe relative volatility of dividends to the corresponding earnings. This study follows this as the second measure of dividend smoothing. First, scaled earnings are calculated by multiplying earnings per share with the firm's target payout ratio in order to remove the scaled effect of the dividend level. Without these two, firms with same earnings volatility and same change in the dividend, the one with the larger dividend exhibits higher dividend volatility. Following Leary and Michaely (2011) quadratic time trend is fitted to both dividend per share and scaled earnings.

$$
\begin{gathered}
D P S_{i t}=\beta_{0}+\beta_{1} t+\beta_{2} t^{2}+U_{i t} \\
T P R_{i} \times E P S_{i t}=\beta_{0}+\beta_{1} t+\beta_{2} t^{2}+V_{i t}
\end{gathered}
$$

Controlling for the linear trend, reports the same level of dividend smoothing for two firms with one targeting specific DPS and the other targeting specific change in DPS while the square time trend inclusion reports the same level of dividend smoothing for a firm targeting same percentage change in dividends. Equation (4) and (5) were estimated for each firm and then their relative volatility (second 


\section{Z. Ali et al}

measure of dividend smoothing) was measured from the standard deviations of error terms on a rolling window of six years for each firm-year observation, given by Relativevolatility $=\sigma\left(u_{i t}\right) \div \sigma\left(v_{i t}\right)$. Both of these variables (speed of adjustment and relative volatility) are treated as alternative proxies of dividend smoothing. The higher the value of these variables, the lower is the level of dividend smoothing.

\subsubsection{Independent variables}

Board structure-related variables used are board's size, board independence, audit committee size, audit committees' independence and audit quality of firms in Pakistan. A binary variable represents whether the firm is audited by the

Table 2: Definition of variables

\begin{tabular}{|c|c|c|}
\hline Variable & Description & Relation \\
\hline \multicolumn{3}{|l|}{ Dependent variables } \\
\hline $\begin{array}{l}\text { Speed of adjustment } \\
\text { (SOA) }\end{array}$ & Estimated via equation (3) & \\
\hline $\begin{array}{l}\text { Relative } \quad \text { volatility } \\
\text { (Rel_Vol) }\end{array}$ & Estimated via equation (4) \& equation (5) & \\
\hline \multicolumn{3}{|l|}{ Control variables } \\
\hline Size (Firm size) & Natural logarithm of total assets & Positive \\
\hline Age (History) & The number of years Since Incorporated. & Negative \\
\hline Risk (Beta) & $\begin{array}{l}\text { Firm's beta at the year-end based on daily prices for } \\
\text { one year }\end{array}$ & Positive \\
\hline Leverage & Total debt divided by total assets of the firm & Negative \\
\hline Tangibility & Tangible assets divided by total assets & Negative \\
\hline Turnover & $\begin{array}{l}\text { Annual average of monthly trade volume of stocks } \\
\text { divided by outstanding shares }\end{array}$ & Negative \\
\hline Cash flows(Cash) & Operating cash flows & Positive \\
\hline \multicolumn{3}{|l|}{ Independent variables } \\
\hline Board size (BSize) & No of the directors on the board of directors & Positive \\
\hline $\begin{array}{l}\text { Board independence } \\
\text { (Bind) }\end{array}$ & $\begin{array}{l}\text { No of non-executive directors in proportion to the } \\
\text { total no of directors. }\end{array}$ & Negative \\
\hline $\begin{array}{l}\text { Big four auditing } \\
(\text { Big4) }\end{array}$ & $\begin{array}{l}\text { dummy } 1 \text { if firm is audited by the big four auditing } \\
\text { firms and } 0 \text { otherwise }\end{array}$ & Positive \\
\hline $\begin{array}{l}\text { Audit committee inde- } \\
\text { pendence(Aind) }\end{array}$ & $\begin{array}{l}\text { No of non-executive directors in audit committee in } \\
\text { proportion to the total no of directors in audit com- } \\
\text { mittee. }\end{array}$ & Negative \\
\hline
\end{tabular}

Source: Author's calculation (2017)

big four auditing firms in Pakistan or not. The big four auditing firms as of December 2016 are A.F Ferguson \& Co, KPMG Taseer Hadi \& Co, Ernst \& Young and Deloitte Touche Tohmastu (M. Yousaf Adil Saleem \& Co). 
3.3 Model designs

\subsubsection{Board structure and dividend smoothing}

The model depicting the impact of board structure on dividend smoothing is given as

$$
\begin{gathered}
S O A=\beta_{0}+\beta_{1} X+\beta_{2} \text { Bsize }+\beta_{3} \text { Bind }+\beta_{4} A i n d+\beta_{5} B i g 4+\epsilon_{i t} \\
\text { RelVol }=\beta_{0}+\beta_{1} X+\beta_{2} B s i z e+\beta_{3} B i n d+\beta_{4} A i n d+\beta_{5} B i g 4+\epsilon_{i t}
\end{gathered}
$$

Then a board index is developed through principal component analysis and its impact is estimated on dividend smoothing.

$$
\begin{gathered}
S O A=\beta_{0}+\beta_{1} X+\beta_{2} \text { Boardindex }+\epsilon_{i t} \\
\text { RelVol }=\beta_{0}+\beta_{1} X+\beta_{2} \text { Boardinde } x+\epsilon_{i t}
\end{gathered}
$$

\subsubsection{Asymmetric dividend smoothing}

Lintner (1956) assumes that firms adjust their dividends at the same rate (SOA) irrespective of whether the firm's last dividend is below the target payout or above. We followed (Leary and Michaely 2011) to relax this assumption. That is; managers are reluctant to announce cuts in dividends than announcing increases (Brav et al 2005). We classified the deviations into two classes in the following pattern.

Dev $_{p}=$ DevifDev $\geq 0$ andotherwise0

Dev $_{N}=$ DevifDev $\geq$ 0andotherwise0

$$
\Delta D_{i t}=\beta_{0}+\beta_{1} D e v_{p}+\beta_{2} D e v_{N}+\epsilon_{i t}
$$

Then the above regression is regressed to investigate the asymmetry of dividend smoothing that whether $\beta_{1}$ and $\beta_{2}$ are different. The null hypothesis for the above model $\beta_{1}=0, \beta_{2}=0$ is to be investigated and both the coefficients need to be positive in order to show convergence towards the target payout ratio. Consequently it is expected that if the cost of announcing an increase in dividend is lower than dividend cuts, then managers are more reluctant to cuts rather than towards announcing increases. Hence they are expected to adjust quickly if they are below the target dividend than when they are adjusting downwards. Ultimately $0<\beta_{2}<\beta_{1}$ is expected.

Similarly, this study investigates whether the board structure variables impact differently adjustment from below and adjustment from above through the

Business Review: (2019) 14(2):65-91 
Z. Ali et al

following equation:

$$
\begin{aligned}
& \Delta D_{i t}=\beta_{0}+\beta_{1} \text { Dev }_{p}+\beta_{2} \text { Dev }_{N} \\
&+ \beta_{3} \text { Bsize }+\beta_{4} \text { Bind }+\beta_{5} \text { Aind }+\beta_{6} \text { Big4 } \\
&+\beta_{7} \text { Dev }_{p} \times \text { Bsize }+\beta_{8} \text { Dev }_{N} \times \text { Bsize } \\
&+\beta_{9} \text { Dev }_{p} \times \text { Bind } \beta_{10} \text { Dev }_{N} \times \text { Bind } \\
&+\beta_{11} \text { Dev }_{p} \times \text { Aind }+\beta_{12} \text { Dev }_{N} \times \text { Aind } \\
&+ \beta_{13} \text { Dev }_{p} \times \text { Big }+\beta_{14} \text { Dev }_{N} \times \text { Big } 4+\epsilon_{i t}
\end{aligned}
$$

\subsubsection{Frequency of dividend changing events in Pakistan}

Following Chemmanur et al (2010) we have classified various dividend changing

\begin{tabular}{|c|c|c|}
\hline & Event & Definition \\
\hline 1 & Increase & $\begin{array}{l}1 \text { if dividend per share in a firm-year has increased } \\
\text { by more than } 10 \%, 0 \text { otherwise }\end{array}$ \\
\hline 2 & Cut & $\begin{array}{l}1 \text { if dividend per share in a firm-year has decreased } \\
\text { by more than } 10 \%, 0 \text { otherwise }\end{array}$ \\
\hline 3 & Continuation & 1 for any increase and decrease $¡ 10 \%, 0$ otherwise \\
\hline 4 & Initiation & $\begin{array}{l}1 \text { if a firm has announced dividend this year and } \\
\text { didn't announce in lag period, } 0 \text { otherwise }\end{array}$ \\
\hline 5 & Omission & $\begin{array}{l}1 \text { if a firm has omitted dividend current year and } \\
\text { announced in the lag period, } 0 \text { otherwise }\end{array}$ \\
\hline 6 & Other & $\begin{array}{l}1 \text { for all events other than initiations and omis- } \\
\text { sions, } 0 \text { otherwise }\end{array}$ \\
\hline
\end{tabular}
events in Pakistan that are dividend increases, dividend cuts, continuations, dividend initiations, dividend omissions and other events. Chi-square test of independence is used for detecting association between dividend changing events and corporate governance related variables.

Table 3: Definitions of dividend events

Source: Author's calculation (2017)

\section{Results and discussion}

\subsection{Dividend payers vs. non-payers}

In this section firm level characteristic of dividend-paying firms is compared to non-paying firms. The first column of table 4 displays mean values of the firm level characteristic of the non-payers while second column displays mean values for dividend payers. The 3rd column displays the difference between the two groups while the last column displays significance that two groups have different mean. For testing the means, we have used two tail t-tests for unequal distributions. Table 4 depicts that dividend-paying firms have higher board independence than non-paying firms. Here, the presence of non-executive directors 
Board structure and dividend smoothing...

Table 4: Dividend payers vs non payers

\begin{tabular}{lccccc}
\hline Variable & Non-payer & Payer & (Non)-(Payer) & Sign $(\mathrm{P})$ & \\
\hline Size & 13.647 & 14.761 & -1.115 & 0.000 & $* * *$ \\
Cash flow & 10.671 & 12.241 & -1.570 & 0.000 & $* * *$ \\
Leverage & 2.046 & 0.647 & 1.399 & 0.124 & \\
Tangibility & 0.634 & 0.534 & 0.100 & 0.000 & $* * *$ \\
Beta & -0.048 & 0.505 & -0.553 & 0.620 & \\
Age & 3.189 & 3.360 & -0.203 & 0.000 & $* * *$ \\
Turnover & 12.243 & 11.972 & 0.271 & 0.001 & $* * *$ \\
Board structure & & & & & \\
Bsize & 0.165 & 0.189 & -0.024 & 0.147 & \\
Asize & 1.187 & 1.183 & 0.004 & 0.738 & $*$ \\
Bind & 0.165 & 0.189 & -0.024 & 0.074 & $*$ \\
Aind & 0.830 & 0.804 & 0.025 & 0.123 & $* * *$ \\
CEO duality & 0.299 & 0.197 & 0.102 & 0.002 & $* * *$ \\
Big4 & 0.360 & 0.566 & -0.206 & 0.000 & $* *$ \\
\hline
\end{tabular}

$* p<0.05, * * p<0.01, * * * p<0.001$

is associated with greater chances of payouts. Therefore it is consistent with the outcome hypothesis of corporate governance i.e. good corporate governance results in high and frequent dividends.

The table also depicts that few dividend paying firms have CEO duality than non-paying firms. That is assigning the role of CEO and chairperson to one person reduces the chances of dividend payments, again consistent with the outcome hypothesis of corporate governance. It is also reported in the results that $56.6 \%$ of the dividend-paying firms are audited by the big four auditors in Pakistan which is again consistent with the outcome hypothesis.

\subsection{Smoothing and non-smoothing firms}

Table 5 compares firm characteristics of high dividend smoothing firms (reflected by low SOA and low relative volatility) with low dividend smoothing firms (having high SOA and high relative volatility). We have estimated the mean of firms' characteristics for each quintile, presented in the five columns. Column 6 in both panels shows the difference in means of the first and last quintile. The last column shows significance with the help of two-way t-test that means the first and last quintile is significantly different. Both panels of table 5 depict that higher dividend smoothing is associated with large boards. Pakistani corporate structure is dominated by families and in such scenario large boards are perceived to be weak monitors. Therefore an alternative monitoring mechanism is adopted through dividend smoothing which is consistent with hypothesis (1) of this study. Similarly, panel B depicts that, firms with low board independence smooth more as an alternative monitoring mechanism which supports the hypothesis (2). Table 5 depicts that higher dividend smoothing is associated with large audit committees. However, the difference between higher smoothers and lower smoothers with respect to audit committee's independence is insignificant, which may be because of the fact that corporate governance rules (2013) prohibit the appointment of non-executive directors on

Business Review: (2019) 14(2):65-91 
Z. Ali et al

Table 5: Firm characteristics across dividend smoothing quintiles

\begin{tabular}{|c|c|c|c|c|c|c|c|}
\hline \multirow[t]{2}{*}{ Panel A: } & \multicolumn{7}{|c|}{ SOA Quintile } \\
\hline & 1 & 2 & 3 & 4 & 5 & Mean(1-5) & Sig \\
\hline \multicolumn{8}{|l|}{ Variable } \\
\hline Size & 14.829 & 14.997 & 15.090 & 15.309 & 15.044 & -0.215 & 0.037 \\
\hline Cash flow & 0.050 & 0.066 & 0.069 & 0.076 & 0.086 & -0.036 & 0.000 \\
\hline Leverage & 0.649 & 0.579 & 0.551 & 0.542 & 0.549 & 0.100 & 0.000 \\
\hline Tangibility & 0.510 & 0.489 & 0.490 & 0.486 & 0.492 & 0.018 & 0.210 \\
\hline Beta & 0.595 & 0.468 & 0.414 & 0.495 & 0.470 & 0.125 & 0.002 \\
\hline Age & 3.458 & 3.489 & 3.445 & 3.492 & 3.371 & 0.088 & 0.006 \\
\hline Turnover & 11.970 & 11.655 & 11.623 & 12.217 & 11.885 & 0.085 & 0.667 \\
\hline \multicolumn{8}{|c|}{ Board structure } \\
\hline Bsize & 2.108 & 2.043 & 2.054 & 2.084 & 2.078 & 0.029 & 0.131 \\
\hline Asize & 1.181 & 1.174 & 1.159 & 1.215 & 1.238 & -0.057 & 0.001 \\
\hline Bind & 0.200 & 0.180 & 0.147 & 0.159 & 0.193 & 0.007 & 0.764 \\
\hline Aind & 0.801 & 0.795 & 0.791 & 0.822 & 0.809 & -0.009 & 0.651 \\
\hline CEO duality & 0.244 & 0.091 & 0.199 & 0.206 & 0.186 & 0.058 & 0.126 \\
\hline Big4 & 0.560 & 0.670 & 0.572 & 0.594 & 0.779 & -0.219 & 0.000 \\
\hline \multirow[t]{2}{*}{ Panel B: } & \multicolumn{7}{|c|}{ Relative Volatility Quintile } \\
\hline & 1 & 2 & 3 & 4 & 5 & $\operatorname{Mean}(1-5)$ & Sig \\
\hline \multicolumn{8}{|l|}{ Variable } \\
\hline Size & 14.676 & 15.031 & 15.215 & 15.178 & 15.152 & -0.476 & 0.000 \\
\hline Cash flow & 0.039 & 0.072 & 0.065 & 0.076 & 0.092 & -0.053 & 0.000 \\
\hline Leverage & 0.685 & 0.559 & 0.557 & 0.549 & 0.528 & 0.157 & 0.000 \\
\hline Tangibility & 0.522 & 0.496 & 0.482 & 0.499 & 0.473 & 0.050 & 0.000 \\
\hline Beta & 0.531 & 0.455 & 0.514 & 0.485 & 0.491 & 0.040 & 0.282 \\
\hline Age & 3.446 & 3.495 & 3.498 & 3.430 & 3.326 & 0.120 & 0.000 \\
\hline Turnover & 11.611 & 11.859 & 12.217 & 12.018 & 11.971 & -0.360 & 0.067 \\
\hline \multicolumn{8}{|c|}{ Board structure } \\
\hline Bsize & 2.101 & 2.044 & 2.082 & 2.071 & 2.059 & 0.042 & 0.009 \\
\hline Asize & 1.146 & 1.162 & 1.175 & 1.226 & 1.253 & -0.107 & 0.000 \\
\hline Bind & 0.158 & 0.189 & 0.168 & 0.141 & 0.209 & -0.052 & 0.018 \\
\hline Aind & 0.801 & 0.803 & 0.805 & 0.801 & 0.819 & -0.018 & 0.299 \\
\hline CEO duality & 0.154 & 0.181 & 0.162 & 0.191 & 0.215 & -0.061 & 0.081 \\
\hline Big4 & 0.498 & 0.536 & 0.647 & 0.703 & 0.762 & -0.264 & 0.000 \\
\hline
\end{tabular}

Source: Author's calculation (2017)

the audit committee. The results for the auditing by any of the four largest auditing firms show that firms audited by them are associated with lower level of dividend smoothing as they are associated with lower level of agency conflict and low-level information asymmetry.

\subsection{Regression results: Board structure and dividend smoothing}

Both columns of the table 6 depict negative association of board size with dividend smoothing measures. It suggests that firms with large boards smooth more dividends in Pakistan. These results are consistent with the hypothesis (H1) of the study which was developed with the notion that large boards have coordination issues and are not efficient monitors. These results are not consistent with the resource dependency theory which gives the notion that a firm's board is a resource and firms with large boards have more linkages with outside and 
can assist management efficiently in making decisions (Carpenter and Westphal 2001; Hassan 2014).

Our result is consistent with the agency view of Jensen (1993), Yermack (1996) and Ghosh and Sirmans (2006), all of these authors associated large boards with weak monitoring because of the coordination issue. Boards have two main roles to perform, resource dependence role and monitoring role. Here this result is consistent with the monitoring role of the board because firms with large boards smooth more which may be because of the weak coordination and weak monitoring of the large boards.

Table 6 depicts that firms with more independent boards have a tendency of less smoothing. It means that firms with lower proportion of non-executive directors; faces a high level of agency conflict and greater information asymmetry exists between outsiders and insiders, alternatively such firms use smooth dividends as an alternative monitoring mechanism. This result affirms hypothesis (H2) of the study and is consistent with the agency and information asymmetry theory of dividend smoothing. It is concluded that firm's managers with independent boards opt for less dividend smoothing. This result is consistent with (Javakhadze et al 2014). Firms with more independent audit committees engage in less dividend smoothing. As hypothesized Pakistan's corporate structure is characterized by concentrated family ownership, therefore, chances of expropriation are high in absence of independent audit committees (Raheja 2005). So this study finds evidence of substitution role of dividend smoothing for audit committees independence. These results are consistent with both agency and information asymmetry theory.

\subsection{Board index}

This study uses principal component analysis (PCA) for developing board index (Board index). Following (Tarchouna et al 2017), we have also chosen the first factor which represents the largest variation of board size, board independence, audit size, audit independence, CEO-duality and audit by big four auditing firms of Pakistan during the sample period. PCA combines these six variables into a linear combination. Table 7 depicts weights of all the mentioned six variables in the board index for Pakistani firms during the sample period based on principal components analysis. Following Tarchouna et al (2017) two concerns were addressed before reporting the index. Kaiser-Meyer-Olkin (KMO) test is used to ensure that correlation between variables is higher than the correlation between errors. KMO statistic was 0.626 well above 0.50. Bartlett's test for sphericity $(\mathrm{P}$-value $<0.001)$ is used to ensure that the variables are factorable.

\subsubsection{Board index and dividend smoothing}

In table 8, the authors have regressed speed of adjustment and relative volatility with the board index developed via PCA by incorporating board size, board independence, audit committee size, audit committee's independence, CEO duality and binary variable distinguishes between firms audited by the four largest

Business Review: (2019) 14(2):65-91 
Table 6: Board structure and dividend smoothing

\begin{tabular}{|c|c|c|}
\hline & (1) & (2) \\
\hline Variables & SOA & Rel Vol \\
\hline Bsize & $\begin{array}{c}-0.129 * * * \\
(0.047)\end{array}$ & $\begin{array}{c}-6.180 * * * \\
(2.154)\end{array}$ \\
\hline Bind & $\begin{array}{c}0.110^{* * *} \\
(0.042)\end{array}$ & $\begin{array}{l}4.295^{* *} \\
(1.917)\end{array}$ \\
\hline Aind & $\begin{array}{c}0.102^{* *} \\
(0.049)\end{array}$ & $\begin{array}{c}8.869^{* * *} \\
(2.265)\end{array}$ \\
\hline Asize & $\begin{array}{l}0.238^{*} \\
(0.122)\end{array}$ & $\begin{array}{l}-3.687 \\
(5.293)\end{array}$ \\
\hline Big4 & $\begin{array}{l}0.064^{*} \\
(0.036)\end{array}$ & $\begin{array}{l}3.066^{*} \\
(1.757)\end{array}$ \\
\hline Size & $\begin{array}{c}-0.050^{* * *} \\
(0.015)\end{array}$ & $\begin{array}{l}-0.835 \\
(0.694)\end{array}$ \\
\hline Cash & $\begin{array}{c}0.219 \\
(0.135)\end{array}$ & $\begin{array}{l}-6.354 \\
(6.246)\end{array}$ \\
\hline Leverage & $\begin{array}{c}0.012 \\
(0.074)\end{array}$ & $\begin{array}{c}4.434 \\
(3.478)\end{array}$ \\
\hline Tangibility & $\begin{array}{c}0.240^{* * *} \\
(0.084)\end{array}$ & $\begin{array}{l}-4.662 \\
(4.025)\end{array}$ \\
\hline Beta & $\begin{array}{l}-0.049 \\
(0.053)\end{array}$ & $\begin{array}{l}-1.389 \\
(2.625)\end{array}$ \\
\hline Age & $\begin{array}{c}-0.034 \\
(0.0359)\end{array}$ & $\begin{array}{c}1.581 \\
(1.606)\end{array}$ \\
\hline Turnover & $\begin{array}{c}0.006 \\
(0.00969)\end{array}$ & $\begin{array}{l}-0.187 \\
(0.459)\end{array}$ \\
\hline Constant & $\begin{array}{c}1.339 * * * \\
(0.240)\end{array}$ & $\begin{array}{c}10.620 \\
(11.350)\end{array}$ \\
\hline Observations & 1094 & 1040 \\
\hline$R^{2}$ & & 0.133 \\
\hline F-Stat & & 6.760 \\
\hline Prob $>F$ & & 0 \\
\hline Left-censored & 123 & \\
\hline Right-censored & 257 & \\
\hline $\mathrm{LR} \chi^{2}(23)$ & 48.850 & \\
\hline Prob $>\chi^{2}$ & 0 & \\
\hline Pseudo $R^{2}$ & 0.026 & \\
\hline Log-likelihood & -91263094 & \\
\hline Industry FE & Yes & Yes \\
\hline
\end{tabular}

Standard errors in parentheses

$* * * p<0.01, * * p<0.05, * p<0.1$

Table 7: Weights of the board index

\begin{tabular}{lc}
\hline Variables & Corp gov index \\
\hline Bsize & 0.547 \\
Bind & 0.200 \\
Asize & 0.546 \\
Aind & 0.347 \\
CEO-Duality & -0.226 \\
Big4 & 0.437 \\
Kaiser-Meyer-Olkin & 0.626 \\
Statistic & \\
Bartlett's test P-value & 0.000 \\
\hline
\end{tabular}

Source: Author's calculation (2017) 
auditing firms or not. A firm scoring high on board index represents strong corporate governance practices through mentioned variables than the one with a low score.

Negative association of board index and dividend smoothing is witnessed, which is in line with the substitution hypothesis. This result is parallel to Leary and Michaely (2011) and Javakhadze et al (2014). As mentioned in the literature review, firms with large boards and audit committees dominated by the executive directors, with entrenched CEOs and not audited by reputed audited firms, have low monitoring ability and greater information asymmetry. Therefore, these results can be explained on the basis of both agency and information asymmetry theory. The results of table 8 are consistent with the substitution hypothesis of La Porta et al (2000).

Table 8: Board index and dividend smoothing

\begin{tabular}{|c|c|c|}
\hline & (1) & $(2)$ \\
\hline Variables & SOA & Rel Vol \\
\hline Board index & $\begin{array}{l}0.0241^{*} \\
\quad(0.0129)\end{array}$ & $\begin{array}{r}1.202^{* *} \\
(0.573)\end{array}$ \\
\hline Size & $\begin{array}{r}-0.0352^{* *} \\
(0.0155)\end{array}$ & $\begin{array}{r}-0.891 \\
(0.696)\end{array}$ \\
\hline Cash & $\begin{array}{l}0.279^{* *} \\
(0.136)\end{array}$ & $\begin{array}{r}-7.319 \\
(6.292)\end{array}$ \\
\hline Leverage & $\begin{array}{r}0.0807 \\
(0.0759)\end{array}$ & $\begin{array}{r}4.102 \\
(3.499)\end{array}$ \\
\hline Tangibility & $\begin{array}{r}0.11 \\
(0.0975)\end{array}$ & $\begin{array}{r}-7.340^{*} \\
(3.967)\end{array}$ \\
\hline Beta & $\begin{array}{r}-0.0339 \\
(0.053)\end{array}$ & $\begin{array}{r}-1.659 \\
(2.642)\end{array}$ \\
\hline Age & $\begin{array}{r}-0.0275 \\
(0.0385)\end{array}$ & $\begin{array}{r}0.569 \\
(1.604)\end{array}$ \\
\hline Turnover & $\begin{array}{r}0.00819 \\
(0.01)\end{array}$ & $\begin{array}{c}-0.0124 \\
(0.462)\end{array}$ \\
\hline Constant & $\begin{array}{r}1.065 * * * \\
(0.259)\end{array}$ & $\begin{array}{r}18.3 \\
(11.34)\end{array}$ \\
\hline Observations & 1094 & 981 \\
\hline $\begin{array}{l}R^{2} \\
\text { F-Stat }\end{array}$ & & $\begin{array}{r}0.1529 \\
9.13\end{array}$ \\
\hline Prob $>$ F & & 0 \\
\hline Left-censored & 123 & \\
\hline Right-censored & 297 & \\
\hline LR $\chi^{2}$ & 3.18 & \\
\hline Prob $>\chi^{2}$ & 0 & \\
\hline Pseudo $R^{2}$ & 0.0533 & \\
\hline Industry FE & Yes & Yes \\
\hline
\end{tabular}

Standard errors in parentheses

$* * * p<0.01, * * p<0.05, * p<0.1$ 


\section{Z. Ali et al}

\subsubsection{Board structure and asymmetric dividend smoothing}

While investigating the asymmetry in dividend smoothing when the firm is above its target level dividend and when it is below the sample was divided into sub samples. Firms' change in dividend from last year is regressed with two variables $D e v_{P}$ and $D e v_{N}$, one, when firm's target dividend is higher than last year dividend (adjusting from below) and second when firm's target dividend is lower than last year dividend (adjusting from above).

The speed of adjustment from below should be higher than speed of adjust-

Table 9: Asymmetric dividend smoothing

\begin{tabular}{lcc}
\hline & $(1)$ & $(2)$ \\
\hline Variables & $D P S_{t}-D P S_{t-1}$ & $D P S_{t}-D P S_{t-1}$ \\
\hline Dev $_{P}$ & $0.396^{* * *}$ & $0.385^{* * *}$ \\
& -0.0426 & -0.0432 \\
Dev $_{N}$ & $0.344^{* * *}$ & $0.366^{* * *}$ \\
& -0.04 & -0.0424 \\
Constant & $0.694^{*}$ & 0.91 \\
& -0.374 & -1.043 \\
Observations & 2526 & 2526 \\
$R^{2}$ & 0.064 & 0.066 \\
F-Stat & 86.44 & 13.76 \\
Prob $>$ F & 0 & 0 \\
Industry FE & No & Yes \\
\hline
\end{tabular}

Standard errors in parentheses $* * * p<0.01, * * p<0.05, * p<0.1$

ment from above (La Porta et al 2000). In line with La Porta et al (2000) firms in Pakistan adjust their dividend at $39.6 \%$ (against $34.4 \%$ from above) for any increase in the earnings when they are adjusting through increases. The higher speed of adjustment from below, than speed of adjustment from above depicts that Pakistani firms are more reluctant to cut dividends than announcing dividend increases. Then we regress the following regression by adding interaction terms of the board variables with positive deviations and negative deviations. Here we observe the impact of these variables on the speed of adjustment from above and below. Table 10 depicts that firms with large boards quickly adjust their dividends towards the target level when the managers are adjusting their dividends from below. It means that board size has a positive influence on speed of adjustment from below. And interestingly firms with large boards try to reduce the speed of adjustment from above. It means that board size doesn't alter the asymmetric behavior of dividend smoothing when firms are adjusting dividends from below or from above rather intensify it. Our result is parallel to (Leary and Michaely 2011).

Audit size effect is more pronounced when firms are adjusting from below. This result is consistent with (Leary and Michaely 2011). Consistent with H2, firms with more proportionate non-executive directors adjust quickly to target dividend when they are adjusting from below. It is is consistent with agency and information theory of dividend smoothing. Board independence plays the 
Board structure and dividend smoothing...

Table 10: Board and asymmetric dividend smoothing

\begin{tabular}{|c|c|c|}
\hline & (1) & $(2)$ \\
\hline Variables & $D P S_{t}-D P S_{t-1}$ & $D P S_{t}-D P S_{t-1}$ \\
\hline \multirow[t]{2}{*}{$\operatorname{Dev}_{P} *$ Bsize } & $4.110^{* * *}$ & $4.091^{* * *}$ \\
\hline & $(0.584)$ & $(0.595)$ \\
\hline \multirow[t]{2}{*}{$\operatorname{Dev}_{N} *$ Bsize } & -0.751 & $-0.812^{*}$ \\
\hline & $(0.470)$ & $(0.491)$ \\
\hline \multirow[t]{2}{*}{$\operatorname{Dev}_{P} *$ Asize } & $-1.717^{* * *}$ & $-1.713^{* * *}$ \\
\hline & $(0.375)$ & $(0.379)$ \\
\hline \multirow[t]{2}{*}{$D e v_{N} *$ Asize } & $-1.622^{* * *}$ & $-1.595 * * *$ \\
\hline & $(0.388)$ & $(0.402)$ \\
\hline \multirow[t]{2}{*}{$\operatorname{Dev}_{P} *$ Bind } & $2.263^{* * *}$ & $2.259^{* * *}$ \\
\hline & $(0.315)$ & $(0.317)$ \\
\hline \multirow[t]{2}{*}{$D e v_{N} *$ Bind } & $-1.095^{* * *}$ & $-1.073^{* * *}$ \\
\hline & $(0.326)$ & $(0.332)$ \\
\hline \multirow{2}{*}{$\operatorname{Dev}_{P} *$ Aind } & $5.244^{* * *}$ & $5.240 * * *$ \\
\hline & $(0.611)$ & $(0.617)$ \\
\hline \multirow[t]{2}{*}{$\operatorname{Dev}_{N} *$ Aind } & $-0.840^{* *}$ & $-0.873^{* *}$ \\
\hline & $(0.374)$ & $(0.386)$ \\
\hline \multirow[t]{2}{*}{$\operatorname{Dev}_{P} * \operatorname{Big} 4$} & 0.352 & 0.342 \\
\hline & $(0.344)$ & $(0.347)$ \\
\hline \multirow{2}{*}{$D e v_{N} * \operatorname{Big} 4$} & 0.634 & 0.676 \\
\hline & $(0.479)$ & $(0.485)$ \\
\hline \multirow[t]{2}{*}{ Bsize } & -6.825 & -7.015 \\
\hline & $(4.219)$ & $(4.354)$ \\
\hline \multirow[t]{2}{*}{ Asize } & 0.696 & 1.397 \\
\hline & $(4.652)$ & $(4.874)$ \\
\hline \multirow[t]{2}{*}{ Bind } & -4.635 & -5.133 \\
\hline & $(3.206)$ & $(3.294)$ \\
\hline \multirow[t]{2}{*}{ Aind } & $9.475^{* *}$ & $9.525 * *$ \\
\hline & $(3.685)$ & $(3.747)$ \\
\hline \multirow[t]{2}{*}{ Big4 } & 1.192 & 1.147 \\
\hline & $(1.745)$ & $(1.883)$ \\
\hline \multirow[t]{2}{*}{$\operatorname{Dev}_{P}$} & $-2.579^{* *}$ & $-2.542^{* *}$ \\
\hline & $(1.022)$ & $(1.037)$ \\
\hline \multirow[t]{2}{*}{$\operatorname{Dev}_{N}$} & $2.933^{* * *}$ & $2.967 * * *$ \\
\hline & $(1.079)$ & $(1.105)$ \\
\hline \multirow[t]{2}{*}{ Constant } & 6.679 & 6.965 \\
\hline & $(8.226)$ & $(9.403)$ \\
\hline Observations & 1069 & 1069 \\
\hline$R^{2}$ & 0.252 & 0.254 \\
\hline F-Stat & 20.87 & 12.64 \\
\hline Prob $>F$ & 0 & 0 \\
\hline Industry FE & No & Yes \\
\hline
\end{tabular}

Standard errors in parentheses

$* * * p<0.01, * * p<0.05, * p<0.1$

substitution role for dividend smoothing only when the firm is adjusting its dividend from below. Firms adjusting from above, exhibit different role of board independence.

Firms having more independent audit committees, adjust their dividends quickly from below. This result affirms (H3) of the study and is line with the agency and information asymmetry theory of dividend smoothing, it supports the substitution role of audit committee independence with dividend smoothing

Business Review: (2019) 14(2):65-91 


\section{Z. Ali et al}

(Javakhadze et al 2014). While looking at the interaction terms of the audit by big four firms with both positive and negative deviations, positive but statistically insignificant coefficients are observed.

\subsubsection{Board structure and dividend changing events}

In this section, the authors have reported how frequently Pakistani firms adjust their dividends. Table 11 depicts the frequency of dividend changing events by classifying them on the basis of board structure characteristics. The changes in dividends are increases, decreases, omissions and initiations of dividends. Table 11 reports frequency of dividend cuts (a decrease of more than $10 \%$ from last year dividend), dividend increases (increase of more than $10 \%$ from last year dividend) and continuations (any dividend change lower than $10 \%$ increase and $10 \%$ decrease). We have divided the sample into two sub samples based on the board size, such that observations having board size greater than the mean value of board size were termed as firms with large boards while those below mean value were termed as firms with small boards.

The first section of panel A of table 11 depicts that firms with large boards have $28.84 \%$ dividend increases as compared to $38.71 \%$ by the firms with small boards. Furthermore, they have $28.13 \%$ cuts against $28.49 \%$ by firms with small boards. As it is shown in the table, firms with large boards have continuations of $43.03 \%$ against $32.8 \%$ by firms with small boards. The null hypothesis of independence of dividend increases and decreases from board size is rejected at $1 \%$ significance level. It is therefore concluded that firms with large boards smooth their dividends more than those with small boards. Similarly firms with large audit committees are frequently changing its dividends via increases and decreases.

Table 11 confirms the associations of dividend changes with board independence at the significance level of $1 \%$ and affirms H2. Firms having more independent audit committees exhibit dividend continuations of $40.2 \%$ against $39.1 \%$ continuations by firms with low audit independence. Firms audited by big four auditing firms have fewer dividend continuations then those not audited by big four. It is consistent with agency and information asymmetry theory of dividend smoothing. At last, we divided the sample based on the board index developed via principal components analysis. Firms having a score above the sample mean on board index were firms practicing good corporate governance via board related variables and others were termed as firms with low board governance. It can be noticed that firms having a high score of board index were having more dividend increases and cuts than other groups. It suggests that firms with low corporate governance use smooth dividends in substitution. This result is parallel to Leary and Michaely (2011) and Javakhadze et al (2014). In this section, we have divided dividend events into three categories, dividend initiations, dividend omissions and others, where initiations are the event when a firm is moving from zero dividends to a positive dividend and omission is the event when a firm is moving from positive dividend to zero dividend.

It was found that initiations events are more than omissions. Moreover, firms with large boards opt for few dividend initiations and omissions then firms with 
Board structure and dividend smoothing...

Table 11: Board structure and frequency of dividend changing events

\begin{tabular}{|c|c|c|c|c|}
\hline Panel A: & Increases & Continuations & Cuts & Total \\
\hline \multicolumn{5}{|l|}{ Board size } \\
\hline \multirow[t]{2}{*}{ Large boards } & 242 & 361 & 236 & 839 \\
\hline & 0.2884 & 0.4303 & 0.2813 & 1 \\
\hline \multirow[t]{2}{*}{ Small boards } & 144 & 122 & 106 & 372 \\
\hline & 0.3871 & 0.328 & 0.2849 & 1 \\
\hline \multirow[t]{2}{*}{ Total } & 386 & 483 & 342 & 1211 \\
\hline & 0.3187 & 0.3988 & 0.2824 & 1 \\
\hline Chi-square tests of independence & 14.6472 & & & \\
\hline (P-Value) & -0.001 & & & \\
\hline \multicolumn{5}{|l|}{ Audit committee size } \\
\hline \multirow[t]{2}{*}{ Large committee } & 11 & 6 & 6 & 23 \\
\hline & 0.4783 & 0.2609 & 0.2609 & 1 \\
\hline \multirow[t]{2}{*}{ Small committee } & 365 & 457 & 331 & 1153 \\
\hline & 0.3166 & 0.3964 & 0.2871 & 1 \\
\hline \multirow[t]{2}{*}{ Total } & 376 & 463 & 337 & 1176 \\
\hline & 0.3197 & 0.3937 & 0.2866 & 1 \\
\hline Chi-square tests of independence & 2.9495 & & & \\
\hline (P-Value) & -0.229 & & & \\
\hline \multicolumn{5}{|l|}{ Board independence } \\
\hline \multirow[t]{2}{*}{ High } & 213 & 219 & 188 & 620 \\
\hline & 0.3435 & 0.3532 & 0.3032 & 1 \\
\hline \multirow[t]{2}{*}{ Low } & 173 & 264 & 156 & 593 \\
\hline & 0.2917 & 0.4452 & 0.2631 & 1 \\
\hline \multirow[t]{2}{*}{ Total } & 386 & 483 & 344 & 1213 \\
\hline & 0.3182 & 0.3982 & 0.2836 & 1 \\
\hline Chi-square tests of independence & 10.7187 & & & \\
\hline (P-Value) & -0.005 & & & \\
\hline \multicolumn{5}{|l|}{ Audit independence } \\
\hline \multirow[t]{2}{*}{ High } & 62 & 76 & 51 & 189 \\
\hline & 0.328 & 0.4021 & 0.2698 & 1 \\
\hline \multirow[t]{2}{*}{ Low } & 310 & 382 & 285 & 977 \\
\hline & 0.3173 & 0.391 & 0.2917 & 1 \\
\hline \multirow[t]{2}{*}{ Total } & 372 & 458 & 336 & 1166 \\
\hline & 0.319 & 0.3928 & 0.2882 & 1 \\
\hline \multirow{3}{*}{$\begin{array}{l}\text { Chi-square tests of independence } \\
\text { (P-Value) } \\
\text { BiG4 }\end{array}$} & 0.37 & & & \\
\hline & -0.831 & & & \\
\hline & & & & \\
\hline \multirow[t]{2}{*}{ Yes } & 283 & 257 & 244 & 784 \\
\hline & 0.361 & 0.3278 & 0.3112 & 1 \\
\hline \multirow[t]{2}{*}{ No } & 110 & 232 & 108 & 450 \\
\hline & 0.2444 & 0.5156 & 0.24 & 1 \\
\hline Total & 393 & 489 & 352 & 1234 \\
\hline & 0.3185 & 0.3963 & 0.29 & 1 \\
\hline Chi-square tests of independence & 42.7054 & & & \\
\hline (p-Value) & 0 & & & \\
\hline Board index & & & & \\
\hline High & 186 & 169 & 165 & 520 \\
\hline & 0.3577 & 0.325 & 0.3173 & 1 \\
\hline Low & 182 & 283 & 163 & 628 \\
\hline & 0.2898 & 0.4506 & 0.2596 & 1 \\
\hline Total & 368 & 452 & 328 & 1148 \\
\hline & 0.3206 & 0.3937 & 0.2857 & 1 \\
\hline Chi-square tests of independence & 18.8141 & & & \\
\hline (P-Value) & 0 & & & \\
\hline
\end{tabular}

Source: Author's calculation (2017)

Business Review: (2019) 14(2):65-91 
Table 12: Board structure and frequency of dividend changing events

\begin{tabular}{|c|c|c|c|c|}
\hline Panel B: & Initiations & Omissions & Others & Total \\
\hline \multicolumn{5}{|l|}{ Board size } \\
\hline \multirow[t]{2}{*}{ Large boards } & 37 & 29 & 260 & 326 \\
\hline & 0.1135 & 0.089 & 0.7975 & 1 \\
\hline \multirow[t]{2}{*}{ Small boards } & 90 & 78 & 467 & 635 \\
\hline & 0.1417 & 0.1228 & 0.7354 & 1 \\
\hline \multirow[t]{2}{*}{ Total } & 127 & 107 & 727 & 961 \\
\hline & 0.1322 & 0.1113 & 0.76 & 1 \\
\hline \multirow{2}{*}{$\begin{array}{l}\text { Chi-square tests of independence } \\
\text { (P-Value) }\end{array}$} & 4.6185 & & & \\
\hline & -0.009 & & & \\
\hline \multicolumn{5}{|l|}{ Audit committee size } \\
\hline \multirow[t]{2}{*}{ Large committee } & 1 & 3 & 15 & 19 \\
\hline & 0.0526 & 0.1579 & 0.7895 & 1 \\
\hline \multirow[t]{2}{*}{ Small committee } & 121 & 102 & 695 & 918 \\
\hline & 0.1318 & 0.1111 & 0.7571 & 1 \\
\hline \multirow[t]{2}{*}{ Total } & 122 & 105 & 710 & 937 \\
\hline & 0.1302 & 0.1121 & 0.7577 & 1 \\
\hline \multirow{2}{*}{$\begin{array}{l}\text { Chi-square tests of independence } \\
\text { (P-Value) }\end{array}$} & 1.2856 & & & \\
\hline & -0.526 & & & \\
\hline \multicolumn{5}{|l|}{ Board independence } \\
\hline \multirow[t]{2}{*}{ High } & 64 & 59 & 317 & 440 \\
\hline & 0.1455 & 0.1314 & 0.7204 & 1 \\
\hline \multirow[t]{2}{*}{ Low } & 66 & 49 & 409 & 524 \\
\hline & 0.126 & 0.0935 & 0.7805 & 1 \\
\hline \multirow[t]{2}{*}{ Total } & 128 & 107 & 729 & 964 \\
\hline & 0.1328 & 0.111 & 0.7562 & 1 \\
\hline \multirow{2}{*}{$\begin{array}{l}\text { Chi-square tests of independence } \\
\text { (p-Value) }\end{array}$} & 4.6529 & & & \\
\hline & -0.096 & & & \\
\hline \multicolumn{5}{|l|}{ Audit independence } \\
\hline \multirow[t]{2}{*}{ High } & 107 & 93 & 575 & 775 \\
\hline & 0.1381 & 0.12 & 0.7419 & 1 \\
\hline \multirow[t]{2}{*}{ Low } & 15 & 11 & 131 & 157 \\
\hline & 0.0955 & 0.0701 & 0.8344 & 1 \\
\hline \multirow[t]{2}{*}{ Total } & 122 & 104 & 706 & 932 \\
\hline & 0.1309 & 0.1116 & 0.7575 & 1 \\
\hline Chi-square tests of independence & 6.1942 & & & \\
\hline (p-Value) & -0.045 & & & \\
\hline BiG4 & & & & \\
\hline Yes & 51 & 37 & 210 & 298 \\
\hline & 0.1711 & 0.1242 & 0.7047 & 1 \\
\hline No & 77 & 72 & 535 & 684 \\
\hline & 0.1126 & 0.1053 & 0.7822 & 1 \\
\hline Total & 128 & 109 & 745 & 982 \\
\hline & 0.1303 & 0.111 & 0.76 & 1 \\
\hline Chi-square tests of independence & 7.7721 & & & \\
\hline (p-Value) & -0.021 & & & \\
\hline Board index & & & & \\
\hline High & 63 & 59 & 329 & 451 \\
\hline & 0.1397 & 0.1308 & 0.7295 & 1 \\
\hline Low & 58 & 43 & 364 & 465 \\
\hline & 0.1247 & 0.0925 & 0.7828 & 1 \\
\hline Total & 121 & 102 & 693 & 916 \\
\hline & 0.1321 & 0.1114 & 0.7566 & 1 \\
\hline Chi-square tests of independence & 4.6711 & & & \\
\hline (P-value) & -0.098 & & & \\
\hline
\end{tabular}

Source: Author's calculation (2017) 
small boards. Table 12 depicts that firms with independent boards experience more initiations and omissions. It depicts that firms with more independent audit committees have a higher number of initiations and omissions than firms with less independent audit committees. We find a significant association of auditing by big four firms with dividend initiations and omissions. While looking at the association of board index with dividend initiations and omission, it is observed that firms having a high score in board index opt for fewer initiations and omissions. These results affirm the substitution role of dividend smoothing.

\section{Conclusion}

This study empirically examined the impact of board structure on dividend smoothing in Pakistan. It found answers to the research questions that whether dividend smoothing is the outcome or substitutes for corporate governance. First, the role of board size in dividend smoothing was explored and it was found that firms with large boards are more likely to smooth their dividends in Pakistan. Firms with large boards are associated with more dividend increases and cuts as compared to those with small boards. Similarly, firms with large boards have more initiations and omissions. Firms with large boards quickly adjust their dividends towards the target level when the managers are adjusting their dividends from below. It suggested that large boards have coordination issues and are not efficient monitors. These results are not consistent with the resource dependency theory which is of the notion that a firm's board is a resource and firms with large boards have more linkages with outside and can assist management efficiently in making decisions (Carpenter and Westphal 2001; Hassan 2014) but the results are consistent with monitoring role of boards under the agency view of Jensen (1993), Yermack (1996) and Ghosh and Sirmans (2006). However, when the firm is adjusting from above, then large boards reduce SOA, but it might be due to the asymmetric behavior of dividend smoothing.

The study found negative association of board independence with dividend smoothing as reflected by multiple regressions via both proxies (SOA and relative volatility). However, the substitution role of dividend smoothing for board independence was only observed when a firm is adjusting their dividends from below. Firms adjusting from above, observe the different role of board independence but it could be because of the asymmetric behavior of dividend smoothing. The non-parametric analysis revealed that firms with high board independence have exhibited higher frequency of dividend increases, cuts, initiations and omissions than firms with low board independence. It means that firms having a lower proportion of non-executive directors; face a high level of agency conflict and greater information asymmetry exists between outsiders and insiders. Alternatively such firms use smooth dividends as an alternative monitoring mechanism. Therefore, it is concluded that weak monitoring because of the low board independence is substituted with smooth dividends. These results are consistent with the monitoring role of boards. So the substitution effect of dividend smoothing for corporate governance is prevailing in a weak shareholder environment like Pakistan (Leary and Michaely 2011; Javakhadze et al 2014).

Business Review: (2019) 14(2):65-91 


\section{Z. Ali et al}

Independent audit committees and dividend smoothing are found to be negatively associated. On the contrary firms having few non-executive directors on the boards opt for a higher level of dividend smoothing. The non-parametric analysis revealed that firms with independent committees have exhibited higher frequency of dividend increases, cuts, initiations and omissions than firms with low board independence. As hypothesized Pakistan's corporate structure is characterized by concentrated family ownership, therefore, chances of expropriation are high in the absence of independent audit committees (Raheja 2005; SetiaAtmaja et al 2009). So we find evidence of the substitution role of dividend smoothing for audit committee's independence. The asymmetric analysis reveals that firms having more independent audit committees adjust their dividends quickly from below. While when the firm is adjusting from above then audit committee's independence slows the adjustment of dividends towards the target dividend. So again the asymmetric behavior of dividend smoothing dominates weak monitoring because of the lack of audit committees.

It suggests that firms with large audit size smooth less dividends which is consistent with the agency and information asymmetry theory. Firms with large audit committees face lower agency conflict and are exposed to a lower level of information asymmetry, hence need less dividend smoothing as alternative mechanism according to the substitution hypothesis (La Porta et al 2000). It shows that audit size effect is more pronounced when firms are adjusting from below. This result is consistent with Leary and Michaely (2011). As market reaction to cuts is more severe than for the increase.

This study depicts via multiple regression analysis that firms audited by big four auditing firms of Pakistan exhibit lower levels of dividend smoothing. Similarly, non-parametric analysis depicted that firms audited by big four firms' exhibit a high number of dividend increases, cuts, initiations and omissions than those not audited by the big four. These results are in line with both the agency and information asymmetry theory. Firms audited by the big four face lower information asymmetry as there are higher chances of detecting frauds by the big four auditing firms.

Board index was developed via PCA by incorporating board size, board independence, audit committee size, audit committee's independence, CEO duality and audit quality. The negative association of board index and dividend smoothing is witnessed, which is in line with the substitution hypothesis. Similarly, firms having a high score of board index were having more dividend increases and cut events than other groups. That is, in a weak corporate governance environment, dividend smoothing is an alternative monitoring mechanism. Firms having high agency conflict and higher information asymmetry between insiders and outsiders because of the weak monitoring power in Pakistan, use more smoothed dividends as alternative monitoring (signaling mechanism) in the light of agency (information asymmetry) theory. Finally, the study found that firms with large boards, low board independence, and low independent audit committees smooth more in Pakistan.

In future this research area could be further investigated by examining the role of the board structure on dividend smoothing in the context of better monitoring and in the context of resource dependency roles proxies of boards. Also 
the impact of investor protection and disclosure quality on dividend smoothing may be investigated.

\section{References}

Allen F, Bernardo AE, Welch I (2000) A theory of dividends based on tax clienteles. The journal of finance 55(6):2499-2536

Armstrong CS, Core JE, Guay WR (2014) Do independent directors cause improvements in firm transparency? Journal of Financial Economics 113(3):383-403

Banerjee A, Chandrasekhar AG, Duflo E, Jackson MO (2013) The diffusion of microfinance. Science 341(6144):1236,498

Beasley MS (1996) An empirical analysis of the relation between the board of director composition and financial statement fraud. Accounting review pp 443-465

Bebchuk L, Cohen A, Ferrell A (2008) What matters in corporate governance? The Review of financial studies 22(2):783-827

Boone AL, Field LC, Karpoff JM, Raheja CG (2007) The determinants of corporate board size and composition: An empirical analysis. Journal of financial Economics 85(1):66-101

Brav A, Graham JR, Harvey CR, Michaely R (2005) Payout policy in the 21st century. Journal of financial economics $77(3): 483-527$

Brennan MJ, Thakor AV (1990) Shareholder preferences and dividend policy. The journal of Finance 45(4):993-1018

Brown LD, Caylor ML (2006) Corporate governance and firm valuation. Journal of accounting and public policy 25(4):409-434

Carpenter MA, Westphal JD (2001) The strategic context of external network ties: Examining the impact of director appointments on board involvement in strategic decision making. Academy of Management journal 44(4):639-660

Chemmanur TJ, He J, Hu G, Liu H (2010) Is dividend smoothing universal?: New insights from a comparative study of dividend policies in hong kong and the us. Journal of Corporate Finance 16(4):413-430

Cheng EC, Courtenay SM (2006) Board composition, regulatory regime and voluntary disclosure. The international journal of accounting 41(3):262-289

Cheung YL, Stouraitis A, Wong AW (2005) Ownership concentration and executive compensation in closely held firms: Evidence from hong kong. Journal of Empirical Finance 12(4):511-532

Cheung YL, Jiang P, Limpaphayom P, Tong L (2008) Does corporate governance matter in china? China Economic Review 19(3):460-479

Cho DS, Kim J (2007) Outside directors, ownership structure and firm profitability in korea. Corporate Governance: An International Review 15(2):239-250

Dahya J, Lonie AA, Power D (1996) The case for separating the roles of chairman and ceo: An analysis of stock market and accounting data. Corporate Governance: An International Review 4(2):71-77

Deshmukh S, Goel AM, Howe KM (2013) Ceo overconfidence and dividend policy. Journal of Financial Intermediation 22(3):440-463

Easterbrook FH (1984) Two agency-cost explanations of dividends. The American economic review 74(4):650-659

Fama EF, Babiak H (1968) Dividend policy: An empirical analysis. Journal of the American statistical Association 63(324):1132-1161

Fama EF, Jensen MC (1983) Separation of ownership and control. The journal of law and Economics 26(2):301-325

Fiegener MK, Brown BM, Dreux IV DR, Dennis Jr WJ (2000) Ceo stakes and board composition in small private firms. Entrepreneurship Theory and Practice 24(4):5-24

Fudenberg D, Tirole J (1995) A theory of income and dividend smoothing based on incumbency rents. Journal of Political economy 103(1):75-93

Ghosh C, Sirmans C (2006) Do managerial motives impact dividend decisions in reits? The Journal of Real Estate Finance and Economics 32(3):327-355

Gillan S, Starks LT (2003) Corporate governance, corporate ownership, and the role of institutional investors: A global perspective. Journal of applied Finance 13(2)

Business Review: (2019) 14(2):65-91 
Z. Ali et al

Gillan SL (2006) Recent developments in corporate governance: An overview

Gompers P, Ishii J, Metrick A (2003) Corporate governance and equity prices. The quarterly journal of economics 118(1):107-156

Gordon MJ (1963) Optimal investment and financing policy. The Journal of finance 18(2):264272

Guttman I, Kadan O, Kandel E (2010) Dividend stickiness and strategic pooling. The Review of Financial Studies 23(12):4455-4495

Hassan M (2014) The impact of corporate governance reforms on board structure and board roles: an empirical study of pakistani listed firms. PhD thesis, Newcastle University

Hermalin BE (2005) Trends in corporate governance. The Journal of Finance 60(5):2351-2384

Hermalin BE, Weisbach MS (1991) The effects of board composition and direct incentives on firm performance. Financial management pp 101-112

How JC, Verhoeven P, Wu CL (2008) Dividends and expropriation in hong kong. Asian Academy of Management Journal of Accounting \& Finance 4(1)

Hu A, Kumar P (2004) Managerial entrenchment and payout policy. Journal of Financial and Quantitative Analysis 39(4):759-790

Javakhadze D, Ferris SP, Sen N (2014) An international analysis of dividend smoothing. Journal of Corporate Finance 29:200-220

Jensen MC (1986) Agency costs of free cash flow, corporate finance, and takeovers. The American economic review 76(2):323-329

Jensen MC (1993) The modern industrial revolution, exit, and the failure of internal control systems. the Journal of Finance 48(3):831-880

Jensen MC, Meckling WH (1976) Theory of the firm: Managerial behavior, agency costs and ownership structure. Journal of financial economics 3(4):305-360

Jeong J (2011) An investigation of dynamic dividend behavior in korea. The International Business \& Economics Research Journal 10(6):21-32

Jeong J (2013) Determinants of dividend smoothing in emerging market: The case of korea. Emerging markets review 17:76-88

Jiraporn P, Kim JC, Kim YS (2011) Dividend payouts and corporate governance quality: An empirical investigation. Financial Review 46(2):251-279

Khanna T, Kogan J, Palepu K (2006) Globalization and similarities in corporate governance: A cross-country analysis. Review of Economics and Statistics 88(1):69-90

Krishna Prasanna P (2014) Firm-level governance quality and dividend decisions: evidence from india. International Journal of Corporate Governance 5(3/4):197-222

Krivogorsky V (2006) Ownership, board structure, and performance in continental europe. The International Journal of Accounting 41(2):176-197

Kumar P (1988) Shareholder-manager conflict and the information content of dividends. The Review of Financial Studies 1(2):111-136

La Porta R, Lopez-de Silanes F, Shleifer A, Vishny R (2000) Investor protection and corporate governance. Journal of financial economics $58(1-2): 3-27$

Lambrecht BM, Myers SC (2010) A litner model of payout and managerial rents. Tech. rep. National Bureau of Economic Research

Leary MT, Michaely R (2011) Determinants of dividend smoothing: Empirical evidence. The Review of Financial Studies 24(10):3197-3249

Linck JS, Netter JM, Yang T (2008) The determinants of board structure. Journal of financial economics $87(2): 308-328$

Lintner J (1956) Distribution of incomes of corporations among dividends, retained earnings, and taxes. The American economic review 46(2):97-113

Lutz J (2015) Committee of sponsoring organizations of the treadway commission: Internal control; integrated framework mit besonderer berücksichtigung der änderungen in der neuauflage 2013

Maury CB, Pajuste A (2002) Controlling shareholders, agency problems, and dividend policy in finland. LTA 1(2):15-45

McMullen DA (1996) Audit committee performance: An investigation of the consequences associated with audit committees. Auditing 15(1):87

Raheja CG (2005) Determinants of board size and composition: A theory of corporate boards. Journal of financial and quantitative analysis 40(2):283-306

Rodriguez-Dominguez L, Gallego-Alvarez I, Garcia-Sanchez IM (2009) Corporate governance and codes of ethics. Journal of Business Ethics 90(2):187 
Ruiz-Barbadillo E, Gomez-Aguilar N, Carrera N (2009) Does mandatory audit firm rotation enhance auditor independence? evidence from spain. Auditing: A Journal of Practice \& Theory 28(1):113-135

Sawicki J (2009) Corporate governance and dividend policy in southeast asia pre-and postcrisis. The European Journal of Finance 15(2):211-230

Setia-Atmaja L, Tanewski GA, Skully M (2009) The role of dividends, debt and board structure in the governance of family controlled firms. Journal of Business Finance \& Accounting 36(7-8):863-898

Setia-Atmaja LY (2009) Governance mechanisms and firm value: The impact of ownership concentration and dividends. Corporate Governance: An International Review 17(6):694709

Sharif M, Rashid K (2014) Corporate governance and corporate social responsibility (csr) reporting: an empirical evidence from commercial banks (cb) of pakistan. Quality \& Quantity 48(5):2501-2521

Sharma V (2011) Independent directors and the propensity to pay dividends. Journal of Corporate finance 17(4):1001-1015

Su Zq, Fung HG, Huang Ds, Shen CH (2014) Cash dividends, expropriation, and political connections: Evidence from china. International review of economics \& finance 29:260272

Tarchouna A, Jarraya B, Bouri A (2017) How to explain non-performing loans by many corporate governance variables simultaneously? a corporate governance index is built to us commercial banks. Research in International Business and Finance 42:645-657

Vafeas N (2000) Board structure and the informativeness of earnings. Journal of Accounting and Public policy 19(2):139-160

Yermack D (1996) Higher market valuation of companies with a small board of directors. Journal of financial economics 40(2):185-211

Business Review: (2019) 14(2):65-91 